\section{Shade Tolerance of St. Augustinegrass Cultivars}

\author{
Laurie E. Trenholm ${ }^{1}$ and \\ Russell T. Nagata ${ }^{2}$
}

AdDitional IndEX wORDs. Floratam, Seville, turf quality

SUMMARY. The objectives of this research were to rank the relative shade tolerance of some new st. augustinegrass (Stenotaphrum secundatum) cultivars and to determine what levels of shade the various cultivars can tolerate. Two consecutive studies were conducted in a glasshouse at the University of Florida Turfgrass Research Envirotron. Cultivars tested were 'Bitter Blue', 'Floratam', 'Palmetto', 'Seville', and '1997-6'. Grasses were grown in full sun or under shade structures that provided $30 \%, 50 \%$, or $70 \%$ shade. In trial 1 , 'Seville' and '1997-6' generally provided best performance under increasing shade, with worst responses seen in 'Floratam'. 'Seville' and '1997-6' were predicted to maintain an acceptable quality rating of 6 at all shade levels. In trial 2, 'Floratam' again had lowest visual quality scores. At $30 \%$ shade, 'Seville', 'Palmetto', and 'Bitter Blue' ranked in the highest category, while only 'Seville' and 'Bitter Blue' had highest rankings at $\mathbf{5 0 \%}$ shade. Reduced density was a major factor in turf decline as shade increased. Most of the cultivars performed best under some degree of shade. With the exception of 'Floratam', acceptable visual scores were maintained at shade levels exceeding $60 \%$ in trial 1 and up to $61 \%$ in trial 2 .

$\mathrm{T}$ urfgrass species differ widely in their responses to reduced light intensity, commonly referred to as shade. Of the warm-season grasses,

\footnotetext{
${ }^{1}$ Environmental Horticulture Department, University of Florida, PO Box 110675, Gainesville, FL 32611

${ }^{2}$ University of Florida, Everglades Research and Education Center, 3200 East Palm Beach Rd., Belle Glade, FL 33430.

Florida Agricultural Experiment Station Journal Series no. (in press)

${ }^{1}$ To whom reprint requests should be addressed. E-mail address: 1trenholm@ifas.ufl.edu.
}

st. augustinegrass is generally considered one of the most shade tolerant grasses (Winstead and Ward, 1974) with differences in degree of tolerance observed within the species (Peacock and Dudeck, 1981).

Previous research has identified typical turf responses to shaded environments. Morphological characteristics include longer leaf length (Wilkinson and Beard, 1974), longer internode lengths (Peacock and Dudeck, 1981; Winstead and Ward, 1974), reduced specific leaf weights (Peacock and Dudeck, 1981; Winstead and Ward, 1974), reduced clipping weights (Barrios et al., 1986; Wilkinson and Beard, 1974), and increased leaf area (Beard, 1973; Peacock and Dudeck, 1981). Reduced tillering and stand density are also considered typical responses to shaded conditions (Beard, 1973). Physiological changes generally include greater chlorophyll concentration (Beard, 1973; Winstead and Ward, 1974), although Peacock and Dudeck (1981) found that shade did not affect the chlorophyll content of various st. augustinegrass cultivars. They also found differences in shoot growth between cultivars under shaded conditions, which they felt may have contributed to lower chlorophyll content.

Barrios et al. (1986) found that turfgrass quality generally declined as shade increased, particularly as shade became more severe. Centipedegrass (Eremochlua ophiuroides) 'Oklawn' was the exception to this, with no decrease in quality due to shade. In contrast to other research reports, Barrios et al. concluded that 'Oklawn' centipedegrass had better tolerance to shade than the st. augustinegrass cultivars. It is also widely reported that turf density decreases as shade increases (Schmidt and Blaser, 1967; Winstead and Ward, 1974), leading to a thinning out of the turf.

Knowledge of what cultivar might perform best under shade is an important issue for builders, landscape designers, and horticulturists. There are some new cultivars of st. augustinegrass available on the market since these previous reports have looked at shade tolerance. The objectives of this experiment were to rank the relative shade tolerance of some new cultivars with standard st. augustinegrass cultivars and to determine what levels of shade the various cultivars can tolerate.

\section{Materials and methods}

Five st. augustinegrass cultivars were established in $15.2-\mathrm{cm}$-diameter (6 inches) plastic pots in Dec. 1999 in a greenhouse at the Envirotron Turfgrass Research Laboratory in Gainesville, Fla. Cultivars included 'Bitter Blue', 'Floratam', 'Palmetto', 'Seville', and the experimental line '1997-6'. 'Bitter Blue and 'Seville' are generally considered to have good shade tolerance, while 'Floratam' has poor shade tolerance (Trenholm et al., 2000). Data are lacking on shade tolerance of 'Palmetto'. Grasses were planted in Metro-Mix 500 (Scott's Co., Marysville, Ohio). Grasses were kept in full sunlight under conditions of optimal irrigation until all pots had established uniform cover, density, and shoot growth. Pots were clipped by hand every other week throughout the experiment at $3.81 \mathrm{~cm}$ ( 1.5 inches). Pots were fertilized throughout the experiment to provide $2.46 \mathrm{~g} \cdot \mathrm{m}^{-2} \mathrm{ni}$ trogen and $1.23 \mathrm{~g} \cdot \mathrm{m}^{-2}$ potassium $(22$ and $11 \mathrm{lb} /$ acre) per month.

Pots were placed in respective shade structures on 20 Jan. 2000. Shade structures measured 111.8 $\mathrm{cm}$ wide $\times 111.8 \mathrm{~cm}$ long $\times 73.7 \mathrm{~cm}$ tall $(44 \times 44 \times 29$ inches $)$ and were covered with a black cloth shade fabric to provide $30 \%, 50 \%$, or $70 \%$ shade. Control pots were placed on a greenhouse bench in full sunlight. Average sunlight in the glasshouse during fall and winter months ranged from 1400 to $1730 \mathrm{umol} \cdot \mathrm{m}^{-2} \cdot \mathrm{s}^{-1}$ in the photosynthetic range. Photoperiod in the greenhouse was extended to $12 \mathrm{~h}$ with $1000-W$ metal halide lamps placed approximately $2 \mathrm{~m}(6.6 \mathrm{ft})$ above the turf canopy. Irrigation was maintained as needed to meet evapotranspiration at the varying shade levels throughout the experiment. The first trial of the experiment was terminated on 11 June 2000. The experiment was repeated from 15 Sept. 2000 through 7 Feb. 2001. Management conditions were similar except that the grass was not mowed every other week, but rather was allowed to grow between shoot harvests.

Data collected during both trials included twice-monthly visual ratings for turf quality, color, and density. Visual scores were ranked from 1 to 9, with 1 equaling dead grass and 9 representing optimal grass appearance, color, and density. A score of 6 was 
considered a minimum value for acceptable turf performance. Leaf blade width and length were taken prior to mowing by randomly selecting three fully expanded leaf blades per pot. Width was measured at the center of the leaf blade and length was measured from the collar to the tip. Shoot growth was measured twice during each trial by mowing the entire pot and collecting all clippings. Clippings were dried at $70.0^{\circ} \mathrm{C}\left(158^{\circ} \mathrm{F}\right)$ for $48 \mathrm{~h}$. Dried clippings were bulked from both harvests for nutrient concentration analysis. Total Kjehdahl $\mathrm{N}$ was determined with a rapid flow analyzer. Nutrient concentration was determined by inductively coupled plasma emission spectrometry for inorganic elements. Shoot count was determined at both terminal harvests.

Experimental design consisted of five st. augustinegrass cultivars nested within four shade treatments with four replications. Data were analyzed by analysis of variance and general linear models of SAS (SAS, 2000). Means separation was determined by the Waller-Duncan $k$-ratio $t$-test. Probability levels of 0.05 were used to determine significant differences between treatments and grasses. Due to numerous significant interactions between the first and second trials, data are presented separately by trial. Within each trial, because significant grass by shade treatment interactions occurred, data are presented by both main factors of shade and grass.

\section{Results}

Trial 1. At all shade treatment levels, 'Seville' consistently ranked in the highest statistical category for quality, color, and density (Table 1). At $30 \%, 50 \%$, and $70 \%$ shade, ' 1997 6' was also in the highest ranking for visual quality and density. Lowest scores at all shade levels were consistently found in 'Floratam'. At 70\% shade, 'Floratam' had lower quality than the other grasses. There were no differences in color scores at $50 \%$ shade and density scores were equal at $50 \%$ shade for all grasses except 'Floratam'. At 70\% shade, only 'Seville' and '1997-6' had acceptable quality ratings of 6 or greater.

Cultivars generally maintained statistically equal quality levels up to $50 \%$ shade treatments (Table 1 ). Color scores tended to be greater or equal in most cultivars at $30 \%$ shade as compared to full sun.

Regression analysis predicted that 'Floratam' would drop below an acceptable quality score of 6 at $56 \%$ shade, while '1997-6' and 'Palmetto' would maintain acceptable quality until $67 \%$ and $68 \%$ shade, respectively (Fig. 1). 'Floratam' was predicted to drop below a score of 6 for density ratings at $61 \%$ shade, while the other cultivars would maintain a score of 6 through $70 \%$ shade (Fig. 2). 'Floratam' had lowest maximum predicted scores but at the highest shade level. Maximum quality was maintained at levels of $16 \%$ to $22 \%$ shade for 'Palmetto' and 'Floratam', respectively, while density began to minimize at $5 \%$ to $19 \%$ shade for 'Bitter Blue' and 'Floratam', respectively. As previously reported by Winstead and Ward (1974) and Schmidt and Blaser (1967), this thinning of turf in shade is a typical response.

In full sunlight, 'Palmetto' and 'Floratam' produced the greatest shoot clipping weights, while 'Bitter Blue' produced the lowest clipping weights (Table 2). 'Palmetto' and 'Seville' had the greatest clipping weights at $30 \%$

Table 1. Average visual quality scores of five st. augustinegrass cultivars at various shade levels in a greenhouse study in two trials. Quality scores were based on a scale from 1 to 9 , where $1=$ dead grass and $9=$ best. Color scores were based on a scale from 1 to 9 , where $1=$ completely chlorotic grass and $9=$ dark green grass. Density scores were based on a scale from 1 to 9 , where $1=$ no grass and $9=$ full coverage.

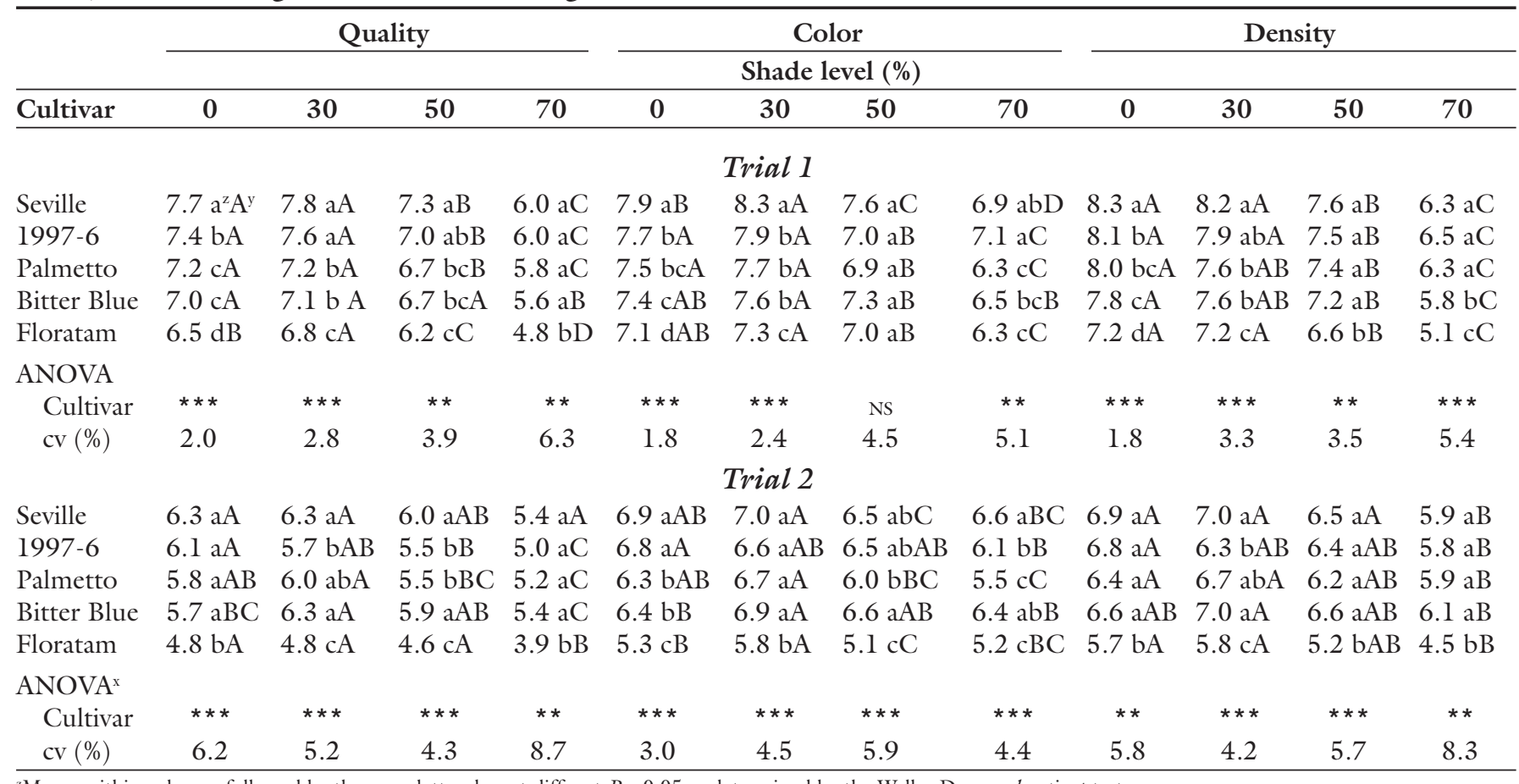

${ }^{2}$ Means within columns followed by the same letter do not differ at $P=0.05$ as determined by the Waller-Duncan $k$-ratio $t$-test.

${ }^{y}$ Means within rows for the three variables followed by the same letter do not differ at $P=0.05$ as determined by the Waller-Duncan $k$-ratio $t$-test.

${ }^{\mathrm{x}}$ Analysis of variance.

${ }_{\mathrm{Ns}, * * *, \star *,}^{*}$ Nonsignificant or significant at $P \leq 0.001,0.01$, or 0.05 , respectively. 


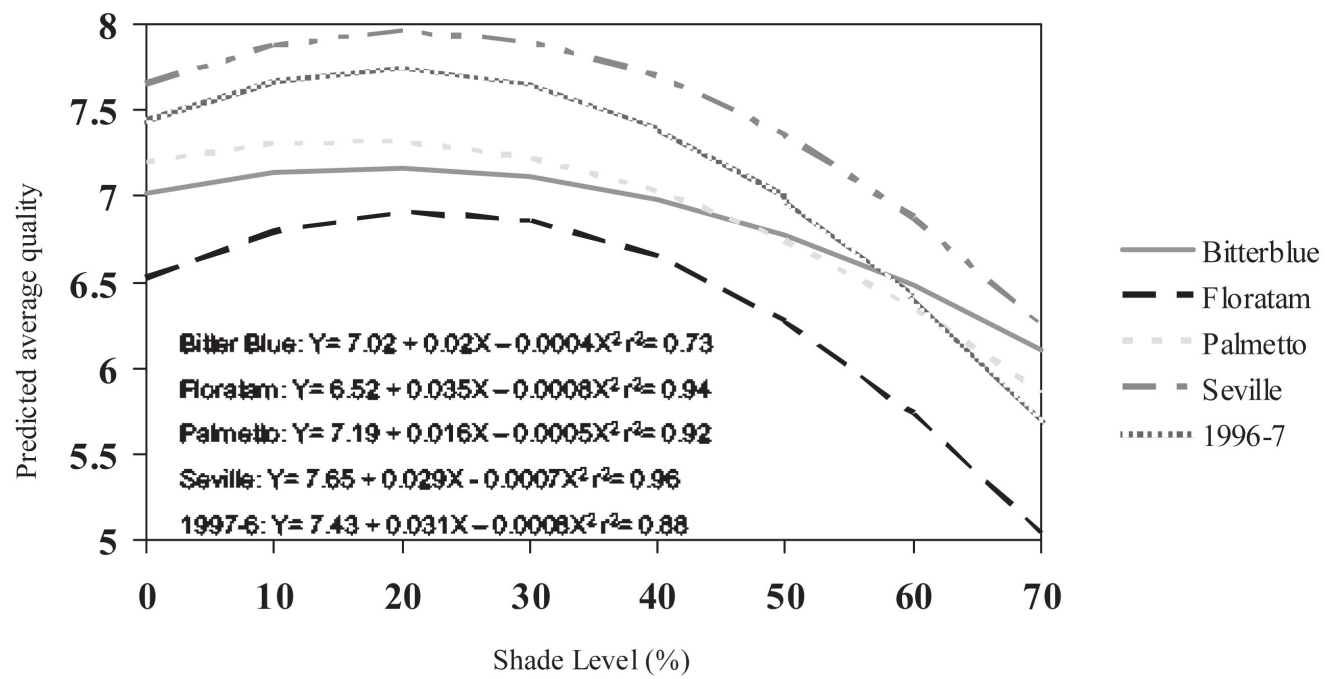

Fig. 1. Predicted quality responses of st. augustinegrass cultivars under various shade levels in trial 1 of a greenhouse study. Quality scores were based on a scale from 1 to 9 , where $1=$ dead grass and $9=$ best.

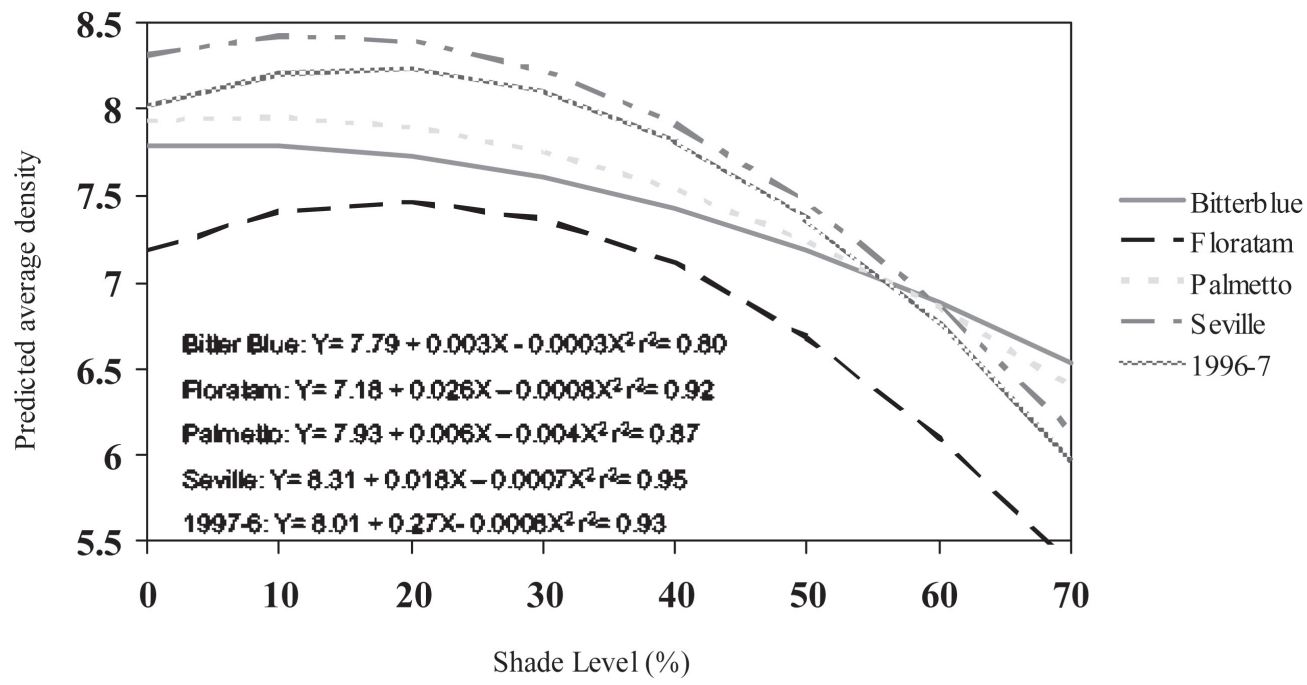

Fig. 2. Predicted density of st. augustinegrass cultivars under various shade levels in trial 1 of a greenhouse study. Density scores were based on a scale from 1 to 9 , where $1=$ no grass and 9 = full coverage.

shade, while at $70 \%$ shade, 'Palmetto' had lower clipping weights than 'Seville', 'Bitter Blue', and '1997-6'. Shoot counts at terminal harvests were greatest in full sun and at $70 \%$ shade in 'Seville' and '1997-6' (Table 2 ) with lowest counts in 'Floratam' in full sun. As seen in the predicted visual density scores, actual shoot count also decreased as shade increased. Under $70 \%$ shade, 'Bitter Blue' had widest leaf blades, while 'Floratam' had longest leaf blades at all shade levels. Although leaf length increased under increasing shade, the reduction in clipping weights at higher shade levels were attributed to reduced shoot count and density in all grasses.

Concentration of nitrogen $(\mathrm{N})$, phosphorus $(\mathrm{P})$, and potassium $(\mathrm{K})$ differed in response to both grass and shade level (Table 3). '1997-6' and 'Palmetto' had higher $\mathrm{N}$ levels than the other cultivars at $0 \%$ and $30 \%$ shade. There were no differences in concentration of any element at 50\% or $70 \%$ shade levels for any cultivar. Nitrogen concentration in all cultivars was reduced at $70 \%$ shade (Table 3 ), while $\mathrm{P}$ and K levels increased as shade increased up to $70 \%$. Decreasing N concentration may indicate a need

for more $\mathrm{N}$ under heavy shade as the grass attempts to produce more leaf tissue to enhance photosynthetic capacity.

Trial 2. 'Floratam' again had the lowest visual scores at all shade levels (Table 1). There were no differences in average quality between the other grasses at $0 \%$ or $70 \%$ shade. At $30 \%$ shade, 'Seville', 'Palmetto', and 'Bitter Blue' ranked in the highest category, while only 'Seville' and 'Bitter Blue' had highest rankings at $50 \%$ shade. Similarly, 'Seville' and 'Bitter Blue' had highest color ratings at $70 \%$ shade. 'Floratam' had lower density scores at $0 \%$, $50 \%$, and $70 \%$ shade than the other cultivars. Quality scores were lower than in trial 1 , probably due to less frequent mowing of the turf in trial 2.

Regression analysis predicted that 'Floratam' and 'Palmetto' would not reach an acceptable quality score of 6 in trial 2 (Fig. 3). Quality scores were also predicted to drop below a score of 6 at $10 \%$ shade for '1997-6', 48\% shade for 'Seville', and 51\% shade for 'Bitter Blue'. Predicted density scores showed that unacceptable scores would be reached at $59 \%$ and $61 \%$ shade with 'Bitter Blue' and 'Seville', respectively (Fig 4). 'Palmetto' and '1997-6' were predicted to maintain acceptable density scores, while

'Floratam' never reached acceptable density levels.

Unlike trial 1, there were few differences in clipping weights between grasses at most shade levels (Table 2). Similarly to trial 1, 'Floratam' had low shoot counts at all shade levels and counts were significantly lower in 'Floratam' at 70\% shade. The only differences between cultivars in leaf width were reported at $70 \%$ shade, where '1997-6' leaves were narrower than 'Palmetto'. At $70 \%$ shade, longest leaves were again found in 'Floratam'.

Of the cultivars tested in this 
Table 2. Clipping weights, shoot counts, leaf width, and leaf length of five st. augustinegrass cultivars under varying shade levels in a greenhouse study in trial 1.

\begin{tabular}{|c|c|c|c|c|c|c|c|c|}
\hline \multirow[b]{3}{*}{ Cultivar } & \multicolumn{4}{|c|}{$\begin{array}{c}\text { Clipping wt } \\
\left(\mathrm{g} \cdot \mathrm{m}^{-2}\right)^{\mathrm{z}}\end{array}$} & \multicolumn{4}{|c|}{$\begin{array}{l}\text { Shoot count } \\
\text { (no./pot) }\end{array}$} \\
\hline & \multicolumn{8}{|c|}{ Shade level (\%) } \\
\hline & 0 & 30 & 50 & 70 & 0 & 30 & 50 & 70 \\
\hline \multicolumn{9}{|c|}{ Trial 1} \\
\hline Palmetto & $0.20 \mathrm{a}^{\mathrm{x}} \mathrm{B}^{\mathrm{w}}$ & $0.25 \mathrm{aA}$ & $0.17 \mathrm{aB}$ & $0.04 \mathrm{bC}$ & $94.0 \mathrm{bcA}$ & $67.8 \mathrm{abB}$ & $68.5 \mathrm{abB}$ & $30.3 \mathrm{bcC}$ \\
\hline Floratam & $0.17 \mathrm{abB}$ & $0.22 \mathrm{bcA}$ & $0.18 \mathrm{aB}$ & $0.05 \mathrm{abC}$ & $49.0 \mathrm{dA}$ & $43.5 \mathrm{bAB}$ & $31.5 \mathrm{cBC}$ & $22.5 \mathrm{cC}$ \\
\hline Seville & $0.16 \mathrm{bB}$ & $0.24 \mathrm{abA}$ & $0.12 \mathrm{aC}$ & $0.07 \mathrm{aD}$ & $120.5 \mathrm{aA}$ & $95.0 \mathrm{aA}$ & $43.0 \mathrm{bcB}$ & $40.0 \mathrm{aB}$ \\
\hline $1997-6$ & $0.15 \mathrm{bB}$ & $0.19 \mathrm{cA}$ & $0.17 \mathrm{aAB}$ & $0.04 \mathrm{aC}$ & $112.0 \mathrm{abA}$ & $76.5 \mathrm{abA}$ & $89.3 \mathrm{aAB}$ & $33.8 \mathrm{abB}$ \\
\hline Bitter Blue & $0.11 \mathrm{cB}$ & $0.15 \mathrm{dA}$ & $0.11 \mathrm{aB}$ & $0.04 \mathrm{aC}$ & $84.8 \mathrm{cA}$ & $47.3 \mathrm{bB}$ & $50.8 \mathrm{bcB}$ & $25.0 \mathrm{cB}$ \\
\hline \multicolumn{9}{|l|}{ ANOVA $^{v}$} \\
\hline Cultivars & ** & $* * *$ & NS & NS & $* * *$ & * & ** & $* *$ \\
\hline $\mathrm{CV}(\%)^{\mathrm{u}}$ & 15 & 12 & 27 & 25 & 18 & 33 & 31 & 18 \\
\hline \multicolumn{9}{|c|}{ Trial 2} \\
\hline Floratam & 10.3 a A & $11.8 \mathrm{abA}$ & $10.9 \mathrm{aA}$ & $4.0 \mathrm{aA}$ & $62.3 \mathrm{bA}$ & $49.8 \mathrm{bAB}$ & $44.8 \mathrm{cB}$ & 18.3 bC \\
\hline $1997-6$ & $9.8 \mathrm{aA}$ & $12.0 \mathrm{abA}$ & $8.4 \mathrm{bB}$ & $4.1 \mathrm{aC}$ & $120.0 \mathrm{aA}$ & $83.8 \mathrm{aB}$ & $49.3 \mathrm{bcC}$ & $39.0 \mathrm{aC}$ \\
\hline Palmetto & $9.6 \mathrm{aA}$ & $13.5 \mathrm{aA}$ & $10.7 \mathrm{abA}$ & $4.0 \mathrm{aB}$ & $128.8 \mathrm{aA}$ & $80.8 \mathrm{aB}$ & $63.3 \mathrm{abcB}$ & $39.0 \mathrm{aC}$ \\
\hline Bitter Blue & $9.5 \mathrm{aA}$ & $12.1 \mathrm{abA}$ & $10.6 \mathrm{abA}$ & $4.1 \mathrm{aB}$ & $125.5 \mathrm{aA}$ & $88.5 \mathrm{aAB}$ & $76.8 \mathrm{aBC}$ & $45.5 \mathrm{aC}$ \\
\hline Seville & $9.3 \mathrm{aA}$ & $10.8 \mathrm{bA}$ & $9.3 \mathrm{abA}$ & $6.0 \mathrm{aA}$ & $101.5 \mathrm{abA}$ & $94.0 \mathrm{aA}$ & $67.8 \mathrm{abB}$ & $35.8 \mathrm{aC}$ \\
\hline \multicolumn{9}{|l|}{ ANOVAw $^{w}$} \\
\hline Cultivars & NS & * & NS & NS & ** & ** & ** & * \\
\hline $\mathrm{CV}(\%)^{\mathrm{u}}$ & 8 & 8 & 14 & 34 & 23 & 15 & 20 & 26 \\
\hline
\end{tabular}

${ }^{2} 1.00 \mathrm{~g} \cdot \mathrm{m}^{-2}=8.922 \mathrm{lb} /$ acre

${ }^{\mathrm{y}} \mathrm{mm}=0.03937$ inch.

${ }^{x}$ Means within columns followed by the same letter do not differ at $P=0.05$ as determined by the Waller-Duncan $k$-ratio $t$-test.

"Means within rows for the three variables followed by the same letter do not differ at $P=0.05$ as determined by the Waller-Duncan $k$-ratio $t$-test.

"Analysis of variance.

"Coefficient of variation.

Ns,***,**,*Nonsignificant or significant at $P \leq 0.001,0.01$, or 0.05 , respectively.

Table 3. Shoot tissue nitrogen, phosphorus, and potassium concentration of five st. augustinegrass cultivars under varying shade levels in a greenhouse study in trial 1 .

\begin{tabular}{|c|c|c|c|c|c|c|c|c|c|c|c|c|}
\hline \multirow[b]{4}{*}{ Cultivar } & & \multirow{2}{*}{\multicolumn{3}{|c|}{$\begin{array}{c}\text { Phosphorus } \\
\left(\mathrm{g} \cdot \mathrm{kg}^{-1}\right)^{\mathrm{z}}\end{array}$}} & \\
\hline & \multicolumn{5}{|c|}{$\begin{array}{r}\text { Nitrogen } \\
\end{array}$} & & & & \multicolumn{4}{|c|}{ Potassium } \\
\hline & \multicolumn{12}{|c|}{ Shade level (\%) } \\
\hline & 0 & 30 & 50 & 70 & 0 & 30 & 50 & 70 & 0 & 30 & 50 & 70 \\
\hline $1997-6$ & $7.7 \mathrm{a}^{\mathrm{y}} \mathrm{A}^{\mathrm{x}}$ & $7.8 \mathrm{aA}$ & $6.7 \mathrm{aA}$ & $1.5 \mathrm{aB}$ & $1.8 \mathrm{abB}$ & $2.3 \mathrm{aA}$ & $2.0 \mathrm{aAB}$ & $2.5 \mathrm{aA}$ & $13.0 \mathrm{cC}$ & $13.7 \mathrm{bBC}$ & $14.9 \mathrm{aB}$ & $22.8 \mathrm{aA}$ \\
\hline Palmetto & $7.4 \mathrm{aA}$ & $7.8 \mathrm{aA}$ & $6.2 \mathrm{aA}$ & $1.4 \mathrm{aB}$ & $1.8 \mathrm{abB}$ & $1.9 \mathrm{bB}$ & $2.2 \mathrm{aB}$ & $2.6 \mathrm{aA}$ & $15.5 \mathrm{abB}$ & $15.9 \mathrm{aB}$ & $16.7 \mathrm{aB}$ & $25.4 \mathrm{aA}$ \\
\hline Floratam & $6.9 \mathrm{bA}$ & $7.1 \mathrm{bA}$ & $7.2 \mathrm{aA}$ & $1.2 \mathrm{aB}$ & $2.1 \mathrm{aB}$ & $2.4 \mathrm{aAB}$ & $2.4 \mathrm{aAB}$ & $2.9 \mathrm{aA}$ & $15.0 \mathrm{aC}$ & $16.3 \mathrm{aC}$ & $17.8 \mathrm{aB}$ & $24.2 \mathrm{aA}$ \\
\hline Seville & $6.8 \mathrm{bA}$ & $7.1 \mathrm{bA}$ & $9.1 \mathrm{aA}$ & $1.4 \mathrm{aB}$ & $1.7 \mathrm{bB}$ & $1.8 \mathrm{bB}$ & $2.6 \mathrm{aA}$ & $2.5 \mathrm{aA}$ & $13.3 \mathrm{bcC}$ & $13.8 \mathrm{bC}$ & $16.8 \mathrm{aB}$ & $21.9 \mathrm{aA}$ \\
\hline Bitter Blue & $6.3 \mathrm{cC}$ & $7.2 \mathrm{bB}$ & $8.6 \mathrm{aA}$ & $1.2 \mathrm{aD}$ & $2.0 \mathrm{abC}$ & $2.3 \mathrm{aBC}$ & $1.8 \mathrm{aB}$ & $3.1 \mathrm{aA}$ & $13.9 \mathrm{a}-\mathrm{cC}$ & $15.6 \mathrm{aBC}$ & $16.5 \mathrm{aB}$ & $24.5 \mathrm{aA}$ \\
\hline \multicolumn{13}{|l|}{ ANOVAw $^{w}$} \\
\hline Cultivars & $* * *$ & ** & NS & NS & 0.06 & $* * *$ & NS & NS & ** & $* * *$ & NS & NS \\
\hline $\mathrm{CV}(\%)^{\mathrm{v}}$ & 3.1 & 4.1 & 12.7 & 16.7 & 10.5 & 7.9 & 26.9 & 17.0 & 5.7 & 3.4 & 11.3 & 9.8 \\
\hline
\end{tabular}

\section{${ }^{\mathrm{z}} 1.0 \mathrm{~g} \cdot \mathrm{kg}^{-1}=1000 \mathrm{ppm}$}

y Means within columns followed by the same letter do not differ at $P=0.05$ as determined by the Waller-Duncan k-ratio t-test.

${ }^{x}$ Means within rows for the three variables followed by the same letter do not differ at $P=0.05$ as determined by the Waller-Duncan $k$-ratio $t$-test.

"Analysis of variance.

${ }^{\mathrm{N}}$ Coefficient of variation.

Ns, ${ }^{* * *}, * *,{ }^{*}$ Nonsignificant or significant at $P \leq 0.001,0.01$, or 0.05 , respectively.

research, best overall quality under increasing shade was found in 'Seville', with the worst shade tolerance in 'Floratam'. Reduced density and shoot counts were major contributors to decline as shade increased, as previously reported by other authors (Schmidt and Blaser, 1967; Winstead and Ward, 1974). Most of the cultivars performed best under some degree of shade with highest visual quality found at up to $33 \%$ shade in 'Palmetto'. With the exception of 'Floratam', acceptable visual scores were maintained at shade levels exceeding 60\% in trial 1 and up to $61 \%$ in trial 2 . While it is doubtful that these quality levels would be maintained under this degree of shade in the landscape over time, it is likely that some degree of shade will improve overall st. augustinegrass performance in the landscape. It is also likely that the best quality and performance in shaded environments will be obtained with a dwarf cultivar such as 'Seville' or '1997-6'. 


\begin{tabular}{|c|c|c|c|c|c|c|c|}
\hline \multicolumn{4}{|c|}{$\begin{array}{l}\text { Leaf width } \\
(\mathrm{mm})^{\mathrm{y}}\end{array}$} & \multicolumn{4}{|c|}{$\begin{array}{l}\text { Leaf length } \\
(\mathrm{mm})\end{array}$} \\
\hline \multicolumn{8}{|c|}{ Shade level (\%)) } \\
\hline 0 & 30 & 50 & 70 & 0 & 30 & 50 & 70 \\
\hline \multicolumn{8}{|c|}{ Trial 1} \\
\hline $7.0 \mathrm{aA}$ & $7.2 \mathrm{aA}$ & $6.7 \mathrm{abAB}$ & $6.3 \mathrm{bB}$ & $59.2 \mathrm{bD}$ & $79.8 \mathrm{bC}$ & $99.2 \mathrm{bB}$ & $161.5 \mathrm{bA}$ \\
\hline 6.9 abA & $7.2 \mathrm{aA}$ & $6.9 \mathrm{aA}$ & $6.2 \mathrm{bA}$ & $69.0 \mathrm{aD}$ & $92.3 \mathrm{aC}$ & $116.6 \mathrm{aB}$ & $213.1 \mathrm{aA}$ \\
\hline $7.3 \mathrm{aA}$ & $7.1 \mathrm{aA}$ & $6.5 \mathrm{abB}$ & $5.4 \mathrm{cC}$ & $50.9 \mathrm{cD}$ & $72.7 \mathrm{cC}$ & $93.4 \mathrm{bB}$ & $156.1 \mathrm{bA}$ \\
\hline $6.3 \mathrm{bAB}$ & $6.5 \mathrm{aA}$ & $6.0 \mathrm{bBC}$ & $5.5 \mathrm{cC}$ & $47.8 \mathrm{cC}$ & $72.4 \mathrm{cB}$ & $90.3 \mathrm{bB}$ & $148.2 \mathrm{bA}$ \\
\hline $7.3 \mathrm{aA}$ & $7.5 \mathrm{aA}$ & $6.9 \mathrm{aA}$ & $7.3 \mathrm{aA}$ & $59.2 \mathrm{bD}$ & $78.3 \mathrm{bcC}$ & $89.3 \mathrm{bB}$ & $164.5 \mathrm{bA}$ \\
\hline$* *$ & NS & * & $* * *$ & $* * *$ & $* * *$ & ** & ** \\
\hline 5 & 7 & 8 & 7 & 6 & 6 & 8 & 10 \\
\hline \multicolumn{8}{|c|}{ Trial 2} \\
\hline $7.6 \mathrm{aA}$ & $7.0 \mathrm{aA}$ & $6.4 \mathrm{aAB}$ & $4.8 \mathrm{abB}$ & $101.8 \mathrm{aC}$ & $192.3 \mathrm{aB}$ & $218.3 \mathrm{aB}$ & $303.7 \mathrm{aA}$ \\
\hline $6.4 \mathrm{aA}$ & $6.0 \mathrm{aB}$ & $5.2 \mathrm{aB}$ & 3.7 bC & $88.9 \mathrm{aB}$ & $130.9 \mathrm{bB}$ & $192.3 \mathrm{aA}$ & $214.2 \mathrm{bcA}$ \\
\hline $6.8 \mathrm{aA}$ & $7.2 \mathrm{aA}$ & $6.2 \mathrm{aA}$ & $5.1 \mathrm{aB}$ & $86.7 \mathrm{aC}$ & $157.5 \mathrm{abB}$ & $204.9 \mathrm{aA}$ & $197.3 \mathrm{cA}$ \\
\hline $6.7 \mathrm{aA}$ & $9.9 \mathrm{aA}$ & $5.3 \mathrm{aA}$ & $4.1 \mathrm{abA}$ & $81.8 \mathrm{aD}$ & $147.3 \mathrm{abC}$ & $176.4 \mathrm{aB}$ & $216.0 \mathrm{cbA}$ \\
\hline $6.6 \mathrm{aA}$ & $6.0 \mathrm{aA}$ & $4.8 \mathrm{aB}$ & $4.5 \mathrm{abB}$ & $90.6 \mathrm{aC}$ & $161.9 \mathrm{abB}$ & $175.9 \mathrm{aB}$ & $231.1 \mathrm{bA}$ \\
\hline NS & NS & NS & NS & NS & NS & NS & $* * *$ \\
\hline 12 & 55 & 19 & 14 & 15 & 18 & 24 & 9 \\
\hline
\end{tabular}
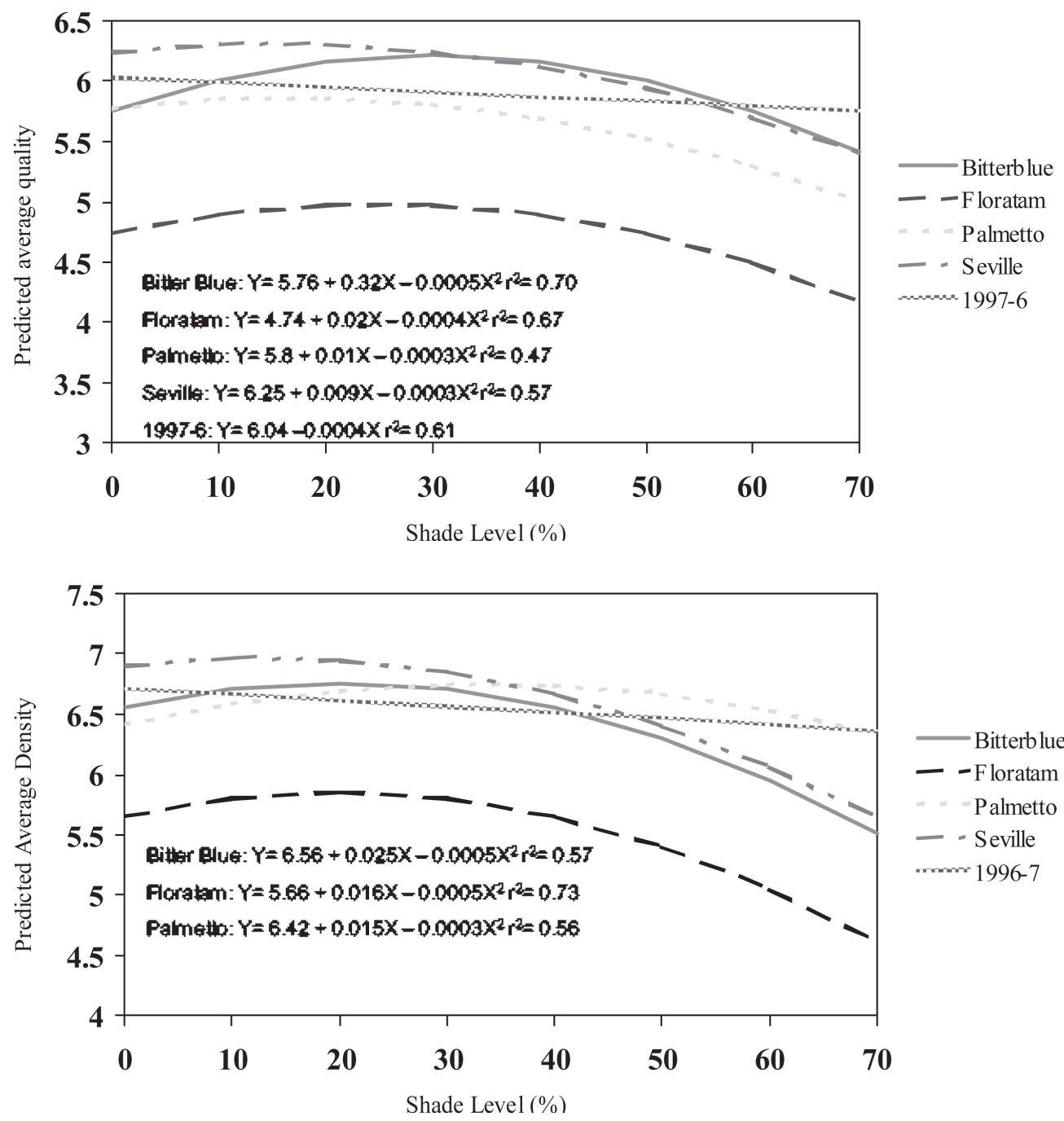

Fig. 3. Predicted quality responses of st. augustinegrass cultivars under various shade levels in trial 2 of a greenhouse study. Quality scores were based on a scale from 1 to 9 , where $1=$ dead grass and 9 = best.

Fig. 4. Predicted density of st. augustinegrass cultivars under various shade levels in trial 2 of a greenhouse study. Density scores were based on a scale from 1 to 9 , where $1=$ no grass and 9 = full coverage 


\section{Literature cited}

Barrios, E.P., F.J. Sundstrom, D. Babcock, and L. Leger. 1986. Quality and yield response of four warm-season lawngrasses to shade conditions. Agron. J. 78:270-273.

Beard, J.B. 1973. Turfgrass: Science and culture. Prentice-Hall, Englewood Cliffs, N.J.

Peacock, C.H. and A.E. Dudeck. 1981. Effects of shade on morphological and physiological parameters of st. augustinegrass cultivars, p. 493-500. In: R.W. Sheard (ed.). Proc 4th Intl. Turfgrass Res. Conf., 19-23 July. Guelph, Ont., Canada.

SAS Institute. 2000. SAS user's guide: Statistics. Vers. 8. SAS Inst., Cary, N.C.

Schmidt, R.E. and R.E. Blaser. 1967. Effect of temperature, light, and nitrogen on growth and metabolism of 'Cohansey' bentgrass (Agrostis palustris Huds.). Crop Sci. 14:563-566.

Trenholm, L.E., J.L. Cisar, and J.B. Unruh. 2000. St. augustinegrass for Florida lawns. Electronic Data Info. Source (EDIS) Coop. Ext. Serv. Fact Sheet ENH5, Univ. of Florida Inst. of Food and Agr. Sci., Gainesville.

Wilkinson, J.F. and J.B. Beard. 1974. Morphological responses of Poa pratensis and Festuca rubra to reduced light intensities, p. 231-240. In: E.C. Roberts (ed.). Proc 2nd Intl. Turfgrass Res. Conf. 19-21 June 1973. Blacksburg, Va.

Winstead, C.W. and C.Y. Ward. 1974. Persistence of southern turfgrasses in a shade environment, p. 221-230. In: E.C. Roberts (ed.). Proc 2nd Intl. Turfgrass Res. Conf. 19-21 June 1973. Blacksburg, Va. 